Int. J. Morphol.,

35(1):16-20, 2017.

\title{
Gestational Diabetes Induces Pancreatic Beta-Cells Apoptosis in Adult Rat Offspring
}

\author{
Diabetes Gestacional Induce Apoptosis de Células Beta del Páncreas en Crías de Ratas Adultas
}

Zahra Nazari ${ }^{1}$; Mohammad Nabiuni²; Soraya Ghaffari ${ }^{3}$; Mohsen Saeidi ${ }^{4}$;

Alireza Shahriyari' ${ }^{5}$ \& Mohammad Jafar Golalipour ${ }^{6}$

NAZARI, Z.; NABIUNI, M.; GHAFFARI, S.; SAEIDI, M.; SHAHRIYARI, A. \& GOLALIPOUR, M. J. Gestational diabetes induces pancreatic beta-cells apoptosis in adult rat offspring. Int. J. Morphol., 35(1):16-20, 2017.

SUMMARY: Several studies indicated that pancreatic $\beta$-cell death occurs in both type 1 and type 2 diabetes. This experimental study was designed to determine the effect of gestational diabetes on the $\beta$-cells in 16 -week-old rat offspring. By this aim, adult Wistar rats aged 10-12 weeks were randomly allocated in control and diabetic groups. The diabetic group received $40 \mathrm{mg} / \mathrm{kg} / \mathrm{body} \mathrm{weight} \mathrm{of}$ streptozotocin (STZ) on day zero of gestation. After delivery, diabetic offspring of GDM mothers and controls at the age of 16 weeks were sacrificed and pancreases harvested and fixed. The number of $\beta$-cells and were counted by Gomori's method staining. Also, apoptosis in pancreas tissue of diabetic and control offspring was detected by TUNEL assay. Results showed a significant reduction in $\beta$-cell number in offspring of GDM $(\mathrm{p}<0.05)$. TUNEL assay showed that the number of apoptotic cells increased in GDM compared to controls $(\mathrm{P}<0.05)$. This study revealed that gestational diabetes induces pancreatic beta-cells apoptosis in 16-week-old rat offspring.

KEY WORDS: Gestational diabetes mellitus; Pancreatic islets (Langerhans); $\beta$-cell; Apoptosis; Rat offspring.

\section{INTRODUCTION}

Diabetes mellitus are multifactorial disorders classified to type 1: an autoimmune $\beta$-cell destruction, type 2: a combination of insulin resistance in peripheral tissues and $\beta$-cell failure and gestational diabetes. Gestational diabetes mellitus (GDM) is a common metabolic disease of pregnancy characterized by hyperglycemia resulting in insulin resistance or failure of sufficient insulin production by pancreatic beta cells (American Diabetes Association, 2014). GDM is a condition affecting approximately $2-10$ $\%$ of all pregnancies in the United States and Europe (Landon \& Gabbe, 2011). Diabetes in pregnant women leads to adverse short-term and long-term metabolic disease states in both the mother and offspring (Lambrinoudaki et al., 2010 \& Vrachnis et al., 2012). Children born to mothers diagnosed with GDM are more susceptible to complex diseases, including obesity, type 2 diabetes and cardiovascular complications during adulthood. Different studies have demonstrated that infants of diabetic mothers have an increased risk for type 2 diabetes in later childhood and as adults (Boloker et al., 2002; Damasceno et al., 2014). Type 2 diabetes is characterized by a progressive decline in beta-cell function and chronic insulin resistance (Butler et al., 2003). Proliferation of insulin-secreting $\beta$-cells in pancreatic islets is an important mechanism for maintaining and adapting islet function to systemic increases in insulin demand. Disruption of $\beta$-cell replication or increased rates of $\beta$-cell death could cause a decrease in $\beta$-cell mass and subsequently reduction in insulin secretion (Ritzel et al., 2006). A few studies reported the adverse effects of gestational diabetes on pancreas of rat offspring. Limitations of study and the multiplicity of factors like feeding behavior and diet make it difficult to explore the pathophysiological mechanisms of gestational diabetes-induced diabetes in offspring. So, animal models of GDM provide an important research tool for investigation of this issue. Induction of hyperglycaemia in

\footnotetext{
${ }^{1}$ PhD candidate, Department of Animal sciences, Faculty of Biological Sciences, Kharazmi University, Tehran, Iran.

${ }^{2}$ Associate Professor, Department of Cell and Molecular Biology, Faculty of Biological Sciences, Kharazmi University, Tehran, Iran.

${ }^{3}$ MSc, Gorgan Congenital Malformations Research Center, Golestan University of Medical Sciences, Gorgan, Iran.

${ }^{4}$ Assistant Professor, Stem cell research center Faculty of Medicine, Golestan University of Medical Sciences, Gorgan, Iran.

${ }^{5} \mathrm{PhD}$ candidate, Stem cell research center, Faculty of Medicine, Golestan University of Medical Sciences, Gorgan, Iran.

${ }^{6}$ Professor, Gorgan Congenital Malformations Research Center, Golestan University of Medical Sciences, Gorgan, Iran.

Funding: This study was funded by Golestan University of Medical Sciences (grant number: 237936).
} 
pregnant rats by streptozotocin injection has been reported in previous studies. Mild maternal hyperglycaemia induced by streptozotocin causes foetal hyperglycaemia, hyperinsulinaemia and macrosomia (Merzouk et al., 2000; Golalipour et al., 2010, 2012). However, it is unknown whether $\beta$-cell apoptosis is increased in offspring of diabetic rats. Therefore, this experimental study was designed to assess the effect of gestational diabetes on the b-cell mass and apoptosis in pancreatic islets of rat offspring in the postnatal 16 weeks of Wistar rats.

\section{MATERIAL AND METHOD}

The entire protocol was reviewed and approved by the Institutional Animal Care and Use Committee at the Golestan University of medical sciences, Gorgan, Iran.

Generation of the diabetic rat model. Adult Wistar rats aged 10-12 weeks were used in this study. The rats were kept in a temperature-controlled environment $\left(21 \pm 2{ }^{\circ} \mathrm{C}\right)$, on $12 \mathrm{~h}$ light/dark cycles, and given free access to tap water and standard rat chow. Female Wistar rats were separately housed with a male for copulation. Vaginal plaque was mentioned daily as a positive sign of pregnancy and the day on which Vaginal plaque was seen and was considered day 0 of pregnancy. We used 21 pregnant rats, allocated in control $(n=7)$ and diabetic $(n=14)$ groups. Diabetic group rats were made diabetic by single intraperitoneal injection of freshly prepared STZ solution (40 $\mathrm{mg} / \mathrm{kg}$ body weight) in sterile saline solution $(0.85 \%)$ on day 1 of gestation (Pasek \& Gannon, 2013). control group rats were injected with equivalent volume normal saline. Four days later, blood glucose levels were checked using a glucometer (ACCU$\mathrm{CHEK}^{\circledR}$ Active Glucometer, Roche Diagnostics, Germany).

If glucose levels were between $120-250 \mathrm{mg} / \mathrm{dl}$, the rats were selected and used as GDM. The pregnant rats were allowed to deliver spontaneously. After offspring reached puberty, their Blood glucose level was estimated with a glucometer. A total of six diabetic offspring from GDM mothers at the age of 16 weeks were selected. Offspring from normal pregnant rats were used as controls. Rats were sacrificed and whole pancreas tissue was dissected and fixed in bouin fixative and $4 \%$ paraformaldehyde for Gomori's Trichrome Staining and tunnel test respectively. Then tissue samples were paraffin embedded for microscopic examination in accordance with routine laboratory procedures.

Gomori's Trichrome Staining. Gomori's chrome alumhematoxylinphloxine stain distinguishes the alpha and beta cells of the pancreas. Histopathologic examination and grading were carried out on Gomori's chrome alumhematoxylinphloxine stain (Gomori, 1941). The number of islets and the number of $\beta$-cells of each islet were counted by Olympus BX 51 microscope and DP12 digital camera attached to OLYSIA autobio report software (Olympus Optical, Co. LTD, Tokyo, Japan). Furthermore, the islet diameters were measured using calibrated micrometer. In each sample, ten similar sections of pancreas tissue were selected and images of five separate fields were captured.

TUNEL staining. Apoptosis in pancreas tissue of diabetic and control offspring was detected by means of the terminal deoxynucleotidyl transferase (TdT)-mediated 2deoxyuridine 5-triphosphate (dUTP) nick-end labeling (TUNEL) assay, according to the kit instructions (Roche, Germany). Briefly, pancreases from diabetic and control groups immediately fixed by $4 \%$ paraformaldehyde for $12 \mathrm{~h}$ at room temperature.

Sections of $5 \mathrm{~mm}$ in thickness were cut and adhered to glass slides using $0.1 \%$ poly-L-Lysine (Sigma) and then dried at room temperature $\left(25^{\circ} \mathrm{C}\right)$. The Roche Molecular Biochemicals In Situ Cell Death Detection Kit was used according to the manufacturer's instructions. After rinsing with PBS, samples were analyzed under a light microscope using Olysia Bio software.

Statistical analysis. Morphometric data is expressed as the mean \pm SEM and analyzed by the Student's t test using SPSS 16.5 software, significance level was set 0.05 .

Ethical approval. All applicable international, national, and/or institutional guidelines for the care and use of animals were followed.

\section{RESULTS}

Blood glucose measurements. Fasting blood glucose concentration was significantly increased in infants of diabetic rats (Fig. 1). At 16 weeks of age, about $60 \%$ of the IDMs developed mild hyperglycemia and glucose levels were markedly elevated compared to controls $(\mathrm{P}<0.001)$.

Morphometric analysis. Data from Gomori's Trichrome Staining of pancreatic islets in diabetic and control offspring are shown in Table I. The mean \pm SE of b-cells number in control and diabetic group was 99.74 \pm 7.10 and $65.21 .56 \pm 6.26$, respectively. This difference was significant $(\mathrm{p}<0.05)$. 
Cell apoptosis. As shown in Fig. 2, Apoptotic $\beta$-cell was identified by TUNEL staining. Our results showed that in the diabetic pancreas the number of apoptotic cells is increased compared to normal pancreas. Mean \pm SE of apoptotic $\beta$-cells number in control and diabetic group was $8.24 \pm 2.3$ and $23.46 \pm 3.34$ respectively (Table I).

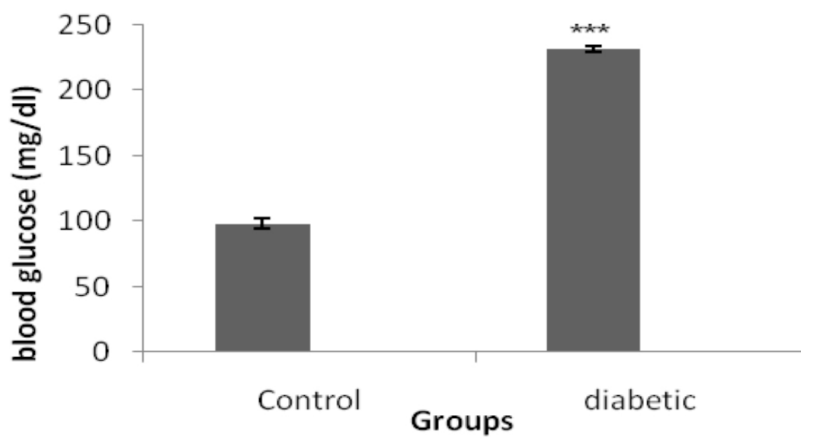

Fig. 1: Blood glucose concentrations in IDMs and control animals (week 16). Blood glucose level of offspring was obtained via tail vein and was estimated with ACCU-CHEK glucometer. Values are means \pm SEM. $* * * \mathrm{P}<0.001$

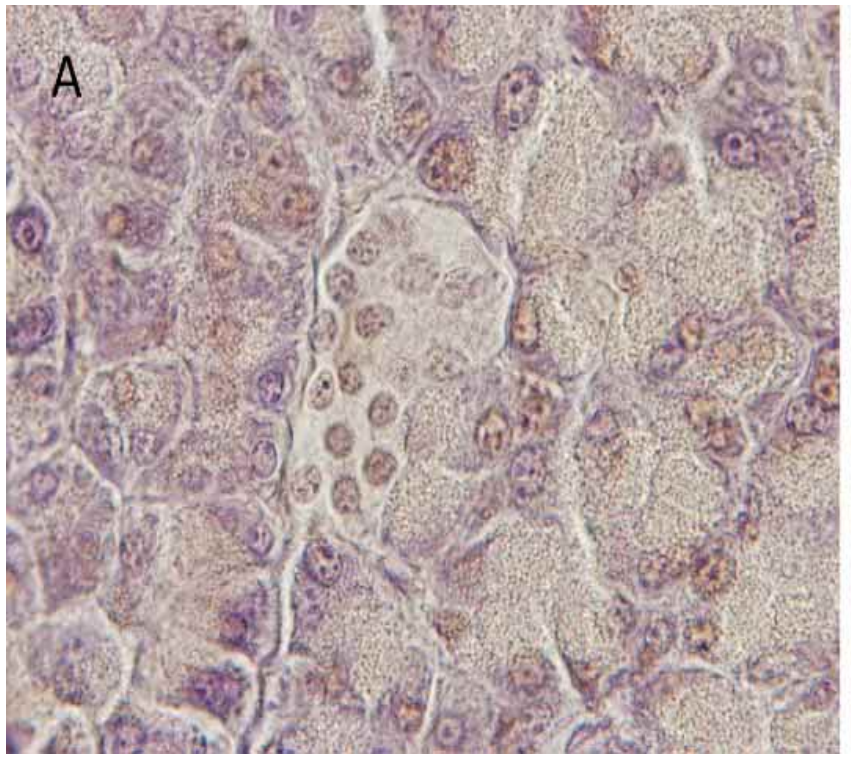

\section{DISCUSSION}

This study was designed to investigate the pancreatic beta cell apoptosis in the offspring of mildly hyperglycaemic rats. We used streptozotocin treatment of pregnant Wistar rats to induce mild maternal hyperglycaemia, resulting in hyperglycaemic offspring. The results of our study demonstrate that GDM reduced the beta cell in pancreas tissue of adult offspring. Also, the results of TUNEL staining demonstrated that GDM increased apoptosis in pancreatic beta cells of offspring.

It has proved that the first years of life in humans, and the first postnatal months of life in rodents, are critical periods of pancreatic $\beta$-cells growth that result in establishment of appropriate $\beta$-cells mass (Georgia \& Bhushan, 2004; Kushner et al., 2005; Teta et al., 2005 \& Meier et al., 2008). Fetal hyperglycemia is a consequence of maternal hyperglycemia that may disturb $\beta$-cells growth during early postnatal period and causes diabetes in offspring later in life.

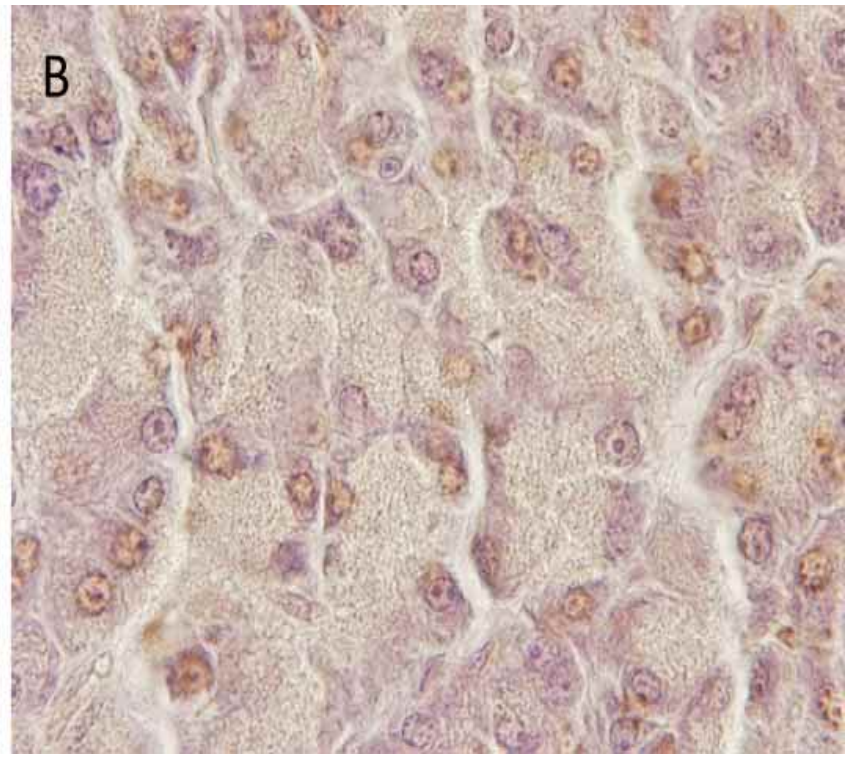

Fig. 2. Photomicrographs of TUNEL-stained rat pancreatic section of Control (A) and Diabetic (B) group. The apoptotic beta cells are shown brown and the non-apoptotic beta cells are blue. Few apoptotic $\beta$-cells were observed in normal pancreas, while in diabetic group the number of apoptotic cells markedly increased. Original magnification X1000.

Table I. The number of b cells, number of apoptotic beta cells of Control and Diabetic Group. Results are expressed as Mean \pm SE of the mean (*p-value $<0.05$, ** p-value $<0.01$ ).

\begin{tabular}{lcc}
\hline \multicolumn{3}{c}{ Characters of pancreatic islets in 16 weeks offspring of gestational diabetes and control } \\
& control & Gestational diabetic \\
\hline Number of beta cells $/ 10000 \mu \mathrm{m}^{2}$ of pancreatic islets & $99.74 \pm 7.10$ & $65.21 \pm 6.26^{*}$ \\
Number of apoptotic beta cell $/ 10000 \mu \mathrm{m}^{2}$ of pancreatic islets & $7.84 \pm 2.3$ & $23.46 \pm 3.34^{* *}$ \\
\hline
\end{tabular}


Previous studies unequivocally demonstrate that there are persistent effects of gestational diabetes on glucose homeostasis in the offspring (Aerts et al., 1990). Consistent with our previous studies (Ritzel et al. \& Golalipour et al., 2012), offspring rats mainly developed hyperglycemia during adulthood. Mean \pm SE of blood glucose in control and diabetic group was 98.5 and $232 \mathrm{mg} / \mathrm{dl}$ respectively $(\mathrm{P}<0.001)$.

Recent studies showed a significant reduction in bcell mass in patient with diabetes (both type 1 and type 2) (Butler et al. \& Meier et al., 2005). In type 1 diabetes, it has shown that $\beta$-cell mass is reduced by $70-80 \%$ at the time of diagnosis. Also, our previous study on rat model of diabetes has shown that STZ markedly cause reduction in $\beta$-cell mass and pancreatic islets in adult rats (Golalipour et al., 2010). In this study, we demonstrated the induced diabetes mellitus diabetes during pregnancy significantly reduced in beta cell density (Table I). These results indicated that in utero exposure to impaired glucose homeostasis has severe consequences and alters the growth of $\beta$-cells in the adults.

We also surveyed the apoptosis in pancreatic islets of GDM and normal offspring. Our result showed more than threefold increase in $\beta$-cell apoptosis in GDM offspring at 16 weeks of life (Table I). In type 2 diabetic subjects, initial pathological studies suggested a $\beta$-cell apoptosis of $25-50$ $\%$. Furthermore, it was shown that $\beta$-cell apoptosis causes a gradual $\beta$-cell depletion in rodent models of type 1 diabetes (Cnop et al., 2005; Eizirik \& Mandrup-Poulsen, 2001).
Identification of factors that induce apoptosis in pancreatic b-cell is necessary. There is strong evidence that IL-1 $\beta$ contributes to $\beta$-cell apoptosis in type 2 and type 1 diabetes via activation of NF-KB. NF-KB activation leads to production of nitric oxide $(\mathrm{NO})$ and depletion of endoplasmic reticulum (ER) calcium (Ammendrup et al., 2000; Cnop et $a l$.). So, IL-1 $\beta$ pathway may be a possible mechanism for $\beta$ cell apoptosis in infants of GDM. Together with previous observation, $\beta$-cell apoptosis may thus be a common feature of diabetes including type 1 diabetes, type 2 diabetes, gestational diabetes and diabetes in the offspring of GDM.

In conclusion, our data showed that $\beta$-cells number reduces in offspring of rats with mild hyperglycemia. Furthermore, diabetic offspring had significantly more apoptotic beta cells than controls. Despite the importance of the metabolic consequences of GDM, no detailed study has been conducted on the effect of maternal diabetes on pancreatic beta cell changes in the offspring. Taken together this study may help toward understanding of the mechanism underlying GDM caused diabetes in the offspring.

\section{ACKNOWLEDGEMENTS}

We acknowledge the support of Golestan University of Medical Sciences for financial support of this research. This article is derived from thesis of Zahra Nazari for $\mathrm{PhD}$ degree in field of developmental biology.

NAZARI, Z.; NABIUNI, M.; GHAFFARI, S.; SAEIDI, M.; SHAHRIYARI, A. \& GOLALIPOUR, M. J. Diabetes gestacional induce apoptosis de células beta del páncreas en crías de ratas adultas. Int. J. Morphol., 35(1):16-20, 2017.

RESUMEN: Varios estudios indican que la muerte de las células $\beta$ del páncreas se produce tanto en la diabetes Tipo 1 como en la Tipo 2. Este estudio experimental fue diseñado para determinar el efecto de la diabetes gestacional en las células $\beta$ del páncreas en crías de ratas de 16 semanas. Para ello, ratas Wistar adultas de entre 10-12 semanas fueron asignadas al azar en dos grupos: control y diabetes. El grupo diabetes recibió $40 \mathrm{mg} / \mathrm{kg}$ / peso corporal de estreptozotocina (STZ) en el día cero de la gestación. Después del parto, a las 16 semanas, las crías de las madres diabéticas y controles de madres con diabetes gestacional (MDG), fueron sacrificadas para la extracción del páncreas, el cual posteriormente fue fijado. Se contó el número de células $\beta$ del páncreas mediante tinción con el método de Gomori. Además, se detectó apoptosis en el tejido del páncreas de la descendencia diabética y el grupo control mediante un ensayo TUNEL. Los resultados mostraron una reducción significativa en el número de células $\beta$ en la descendencia de MDG (p <0,05). El ensayo TUNEL mostró que el número de células apoptóticas aumentó en MDG en comparación con los controles ( $\mathrm{P}<0,05)$. Este estudio reveló que la diabetes gestacional induce apoptosis de células $\beta$ en el páncreas de crías de ratas de 16 semanas.

PALABRAS CLAVE: Diabetes mellitus gestacional; Islotes pancreáticos; Células $\beta$; Descendientes; Apoptosis; Ratas.

\section{REFERENCES}

Aerts, L.; Holemans, K. \& Van Assche, F. A. Maternal diabetes during pregnancy: consequences for the offspring. Diabetes Metab. Rev., 6(3):147-67, 1990.
American Diabetes Association. Standards of medical care in diabetes-2014.

Diabetes Care, 37 Suppl., 1:S14-80, 2014.

Ammendrup, A.; Maillard, A.; Nielsen, K.; Aabenhus Andersen, N.; Serup, 
P.; Dragsbaek Madsen, O.; Mandrup-Poulsen, T. \& Bonny, C. The cJun amino-terminal kinase pathway is preferentially activated by interleukin-1 and controls apoptosis in differentiating pancreatic betacells. Diabetes, 49(9):1468-76, 2000.

Boloker, J.; Gertz, S. J. \& Simmons, R. A. Gestational diabetes leads to the development of diabetes in adulthood in the rat. Diabetes, 51(5):1499506, 2002.

Butler, A. E.; Janson, J.; Bonner-Weir, S.; Ritzel, R.; Rizza, R. A. \& Butler, P. C. Beta-cell deficit and increased beta-cell apoptosis in humans with type 2 diabetes. Diabetes, 52(1):102-10, 2003.

Cnop, M.; Welsh, N.; Jonas, J. C.; Jörns, A.; Lenzen, S. \& Eizirik, D. L. Mechanisms of pancreatic beta-cell death in type 1 and type 2 diabetes: many differences, few similarities. Diabetes, 54 Suppl. 2:S97107, 2005.

Damasceno, D. C.; Netto, A. O.; Iessi, I. L.; Gallego, F. Q.; Corvino, S. B.; Dallaqua, B.; Sinzato, Y. K.; Bueno, A.; Calderon, I. M. \& Rudge, M. V. Streptozotocin-induced diabetes models: pathophysiological mechanisms and fetal outcomes. Biomed. Res. Int., 2014:819065, 2014.

Eizirik, D. L. \& Mandrup-Poulsen, T. A choice of death--the signaltransduction of immune-mediated beta-cell apoptosis. Diabetologia, 44(12):2115-33, 2001.

Georgia, S. \& Bhushan, A. Beta cell replication is the primary mechanism for maintaining postnatal beta cell mass. J. Clin. Invest., 114(7):9638, 2004.

Golalipour, M. J.; Ghafari, S.; Kouri, V. \& Kestkar, A. A. Proliferation of the $\beta$-cells of pancreas in diabetic rats treated with Urtica Dioica. Int. J. Morphol., 28(2):399-404, 2010.

Golalipour, M. J.; Kafshgiri, S. K. \& Ghafari, S. Gestational diabetes induced neuronal loss in CA1 and CA3 subfields of rat hippocampus in early postnatal life. Folia Morphol. (Warsz), 71(2):71-7, 2012.

Kushner, J. A.; Ciemerych, M. A.; Sicinska, E.; Wartschow, L. M.; Teta, M.; Long, S. Y.; Sicinski, P. \& White, M. F. Cyclins D2 and D1 are essential for postnatal pancreatic beta-cell growth. Mol. Cell Biol., 25(9):3752-62, 2005.

Lambrinoudaki, I.; Vlachou, S. A. \& Creatsas G. Genetics in gestational diabetes mellitus: association with incidence, severity, pregnancy outcome and response to treatment. Curr. Diabetes, 6(6):393-9, 2010.

Landon, M. B. \& Gabbe, S. G. Gestational diabetes mellitus. Obstet. Gynecol., 118(6):1379-93, 2011.

Meier, J. J.; Bhushan, A.; Butler, A. E.; Rizza, R. A. \& Butler, P. C. Sustained beta cell apoptosis in patients with long-standing type 1 diabetes: indirect evidence for islet regeneration? Diabetologia, 48(11):2221$8,2005$.

Meier, J. J.; Butler, A. E.; Saisho, Y.; Monchamp, T.; Galasso, R.; Bhushan, A.; Rizza, R. A. \& Butler, P. C. Beta-cell replication is the primary mechanism subserving the postnatal expansion of beta-cell mass in humans. Diabetes, 57(6):1584-94, 2008.

Merzouk, H.; Madani, S.; Chabane Sari, D.; Prost, J.; Bouchenak, M. \& Belleville, J. Time course of changes in serum glucose, insulin, lipids and tissue lipase activities in macrosomic offspring of rats with streptozotocin-induced diabetes. Clin. Sci. (Lond.), 98(1):21-30, 2000.

Pasek, R. C. \& Gannon, M. Advancements and challenges in generating accurate animal models of gestational diabetes mellitus. Am. J. Physiol. Endocrinol. Metab., 305(11):1327-38, 2013.

Ritzel, R. A.; Butler, A. E.; Rizza, R. A.; Veldhuis, J. D. \& Butler, P. C. Relationship between beta-cell mass and fasting blood glucose concentration in humans. Diabetes Care, 29(3):717-8, 2006.

Teta, M.; Long, S. Y.; Wartschow, L. M.; Rankin, M. M. \& Kushner, J. A. Very slow turnover of beta-cells in aged adult mice. Diabetes, 54(9):2557-67, 2005.

Vrachnis, N.; Augoulea, A.; Iliodromiti, Z.; Lambrinoudaki, I.; Sifakis, S. \& Creatsas, G. Previous gestational diabetes mellitus and markers of cardiovascular risk. Int. J. Endocrinol., 2012:458610, 2012.

\author{
Corresponding author: \\ Mohammad Jafar Golalipour \\ Gorgan Congenital Malformations Research Center \\ Department of Anatomical Sciences \\ Golestan University of Medical Sciences \\ 49175-553 \\ Gorgan \\ IRAN
}

Tel : +98 1714425165

Fax: +981714421660

E-mail: mjgolalipour@yahoo.com

Received: 11-06-2016

Accepted: 20-09-2016 